\title{
Phytochemical Screening and Larvicidal Activity of Fermented Garlic to Aedes aegypti and Aedes albopictus (Diptera: Culicidae)
}

\author{
Aidhya Irhash Putra ${ }^{1 *}$, Rina Delfita ${ }^{1}$ \\ ${ }^{1}$ Department of Biology Education, FTIK, IAIN Batusangkar \\ Jln. Sudirman No. 137 Kubu Rajo, Lima Kaum, Tanah Datar \\ *Email: aidhya.ip@iainbatusangkar.ac.id
}

\section{Article History}

Received: 19 April 2021

Revised: 7 May 2021

Accepted: 25 June 2021

Published: 30 June 2021

\section{Key Words}

Fermented garlic;

Phytochemical screening, Aedes aegypti, Aedes albopictus.

\begin{abstract}
The purpose of this study was to determine the effect of larvicidal compounds from garlic fermented on Aedes aegypti and Aedes albopictus as a vector dengue fever (DF) and dengue hemorrhagic fever (DHF) then compare the mortality and identifying active compounds of fermented garlic extract. The third instar larvae of Aedes aegypti and Aedes albopictus is used in this research. It fermented garlic using fungi tempeh for 96 hours. Fermented garlic extracted by using centrifuges at $3500 \mathrm{rpm}$ for 15 minutes and directly used to test larvicides. Larvicidal activity test was carried out with the bioassay test against mosquito third instar larvae with 11 different treatment groups, positive control (abate), negative control, $27.5 \%, 25 \%, 22.5 \%, 20 \%, 17.5 \%, 15 \%, 12.5 \%, 10 \%$ and $7.5 \%$, and each treatment carried out four replications. Larvicidal activity is determined by calculating the percent of mortality for 24 hours to obtain the LC50 value. Phytochemical screening is done with standard procedures and the organophosphorus fraction of ethyl acetate fermented garlic extract using GC-MS. The percentages of larval mortality is $15-85 \%$ of Aedes aegypti and Aedes albopictus from 2.5 to $72.5 \%$. LC 50 value for the larvae of A. aegypty lower (20\%) than the larvae of A. albopictus (21.429\%). Therefore, fermented garlic extract has potential as larvicides. Alkaloids, flavonoids, saponins, polyphenols, and steroids on garlic fermented extract are not identified. 49 organophosphorus compounds are identified and allicin derivative compounds on fermented garlic are the allyl-2,3-Epoxypropyl sulfide.
\end{abstract}

\section{INTRODUCTION}

Dengue fever (DF) and dengue hemorrhagic fever (DHF) are important problems that develop in the tropics and subtropics region and are the most common arboviral disease worldwide (Gubler, 1998). The World Health Organization (WHO) noted Indonesia as the country with the highest dengue cases in Southeast Asia (Kemenkes RI, 2010). Two species of mosquitoes, Aedes aegypti (L.) and Aedes albopictus (Skuse), are competent vector-vectors in Asian countries (Foster \& Walker, 2002)(Rozendaal, 1997), including in Indonesia. These diseases often cause epidemics (Chin, 2006). We have not recommended DF and DHF drugs and vaccines so that countermeasures depend heavily on vector control efforts (Chin, 2006).

Vector control is an effort to reduce the population density of Aedes mosquitoes (Ae. aegypti and Ae. albopictus) to a certain extent so that they do not have the potential to transmit the 
disease. Commonly used measures are the three traditional Aedes indexes, namely the House Index (HI), Container Index (CI), and Breteu Index (BI) (Sanchez et al., 2006). These indices are the transmission threshold (Focks, 2003), as well as indicators for assessing the impact of vector control programs (World Health Organization, 2005). HI according to the Ministry of Health, to prevent dengue transmission, should not be over 5\% (Budiyanto et al., 2007). Vector density in Indonesia (premise index / HI) is estimated at $20 \%$ or $5 \%$ above the risk threshold for transmission. But the results of studies in various regions show a higher number of HI. In Palembang, reached 44.7\% (Budiyanto et al., 2007), in North Jakarta 27.3\% (Hasyimi \& Soekirno, 2004). HI in West Sumatra has not been reported yet, but according to the Head of the West Sumatra Provincial Health Office Rosnimi Safitri, the highest dengue in 2015 was Padang City, with 944 cases. Following Tanah Datar with 345 cases and Agam with 265 cases (HorasNews, 2016). A high case number in these three regions illustrates $\mathrm{HI}$ above the transmission threshold value $(>5 \%)$.

Vector control is an effort to reduce the population density of Aedes control programs in various countries including Indonesia are less successful because they almost completely depend on fogging to kill adult mosquitoes. Head of Yogyakarta City Health Office, Dr. Choirul Anwar, M. Kes said, fogging requires considerable costs $( \pm$ Rp. 1,900,000 to fogging a radius of 200 meters) and enough and trained (inefficient) personnel (Media Info Kota, 2012), causing vector resistance because of doses which is not right, the killing power is only 1-2 days and does not have a long impact because mosquito larvae do not die (Widiarti et al., 2011).

A lot of research has been done on the use of biogenic agents such as plant protective substances, as natural insecticide products such as bio-insecticides (González-Coloma et al., 2010). For example, testing of fumigant effects and contact insecticides from 22 types of plant essential oils in the acantho scelidesobtectus bean beetle (Regnault-Roger et al., 1993). Research on the application of active compounds of garlic has been widely reported, including active compounds of garlic in Sitotroga cerealella (Yang et al., 2012). The substance of garlic such as garlic essential oil is effective in some mosquito species. A study on the toxic effects of garlic methanol extract and garlic essential oil against 3 instar stages of Culex peus, C. tarsalis, Aedes aegypti, A. trisoriatus, A. sirensis and 3 and 4 instar larvae A. nigromaculis who are already resistant (Amonkar \& Reeves, 1970). The results show that the essential oil fraction was more toxic than the crude garlic extract. Larvicidal properties of garlic essential oils that have been isolated and identified as diallyl disulfide and diallyl trisulfide compounds (Amonkar \& Banerji, 1971). Allicin inhibits malaria infection by inhibiting cysteine protease through the process of circumsporozoite protein (CSP) in Plasmodium sporozoites to infect host cells (Coppi et al., 2006). This compound has a fatal effect on Culex pipiens quinquefasciatus.

The compounds contained in plants that have the potential as insides are alkaloids such as tannins, saponins, and glycosides. In garlic tubers that can kill mosquito larvae are groups of tannins, glycosides, and saponins (Huzaifa et al., 2014). Many studies have been conducted on the testing of compounds derived from plants that are insecticides, but the information about insects from natural fermentation materials is very limited. It is suspected that fermented garlic has a new substance which differs from the extract of fresh garlic (Delfita \& Putra, 2015) because it has undergone a process of decomposition by microbes. We also thought its potential as an insecticide agent to be quite large, considering that microbial metabolites formed during fermentation produce many active compounds. Facts on the ground also found that garlic is one of the ingredients in making natural insecticides. Garlic that has been mashed and other ingredients are mixed and then fermented for one week.

The purpose of this study was to determine the differences in mortality of Aedes aegypti and Aedes albopictus larvae with fermented garlic extract. The specific purpose of this study was to compare the mortality of Aedes aegypt mosquito larvae and Aedes albopictus with fermented garlic extract, comparing the mortality of Aedes mosquito larvae by giving fermented garlic extract at different concentrations and identifying active compounds of fermented garlic extract. 


\section{METHOD}

The method used in this study is the experimental method. This study uses Aedes aegypti and Ae larvae albopictus instar IV and divided into 11 treatment groups and it carried each extract treatment for 4 times.

\section{Research Procedure Fermentation}

Liquid fermentation fermented garlic using tempeh mushrooms. Garlic peeled, washed, boiled, mashed. 20 grams of fine garlic added $20 \mathrm{~mL}$ of sterile distilled water, then sterilized heat (fermentation medium). Inoculation of 5\% Tempe mushroom into a fermentation medium with fermentation duration was 96 hours (Delfita \& Putra, 2015).

\section{Fermented Garlic Extraction}

Extraction by centrifuging at $3500 \mathrm{rpm}$ for 15 minutes. We collected the supernatant to test for larvicidal activity. We stored extraction results in the refrigerator until larvacide testing and phytochemical characterization (Delfita \& Putra, 2015).

\section{Phytochemical Screening of Fermented Garlic}

Phytochemical screening includes alkaloid test, flavonoid test, saponin test, polyphenol test, and steroid test. It took samples of fermented garlic extract to the Sumatra Biota Laboratory UPT Andalas Padang University for phytochemical screening, according to the standard phytochemical method procedure (Harborne, 1973).

\section{Identification of Organosulfur Compounds of Fermented Garlic}

Organosulfur compounds fermented we identified garlic extract using GC-MS. We previously identified fractionation using ethyl acetate by mixing 1 part fermented garlic extract with 3 parts ethyl acetate. Fractionation results obtained a concentrated gold colored solution, and this solution was used to identify organosulfur compounds of fermented garlic. This ethyl acetate fraction was taken to the UPTD Padang Pangilun Health Laboratory Center to identify the organosulfur content of fermented garlic.

\section{Provision of Mosquito Larvae}

Aedes mosquito larvae are taken directly from the field. It took larvae from the Dobok Lima Kaum area, Tanah Datar. Ae.aegypti and Ae larvae. albopictus is identified by observing the 8th abdomen. Ae larvae. albopictus has a distinctive and thornless tooth comb on the lateral part of the thorax. Ae larvae. Aegypti has a comb scale that amounts to 8-21 and is lined up 1-3 and there are spines on the lateral part of the thorax (Taboada, 1967). Adult mosquitoes Ae aegypti on both sides of the lateral side of the head are found some kind of white line, while in the head Ae. albopictus is only found in a straight line in the middle of the head. The 4th instar larvae are characterized by observing $5-6 \mathrm{~mm}$ in size and dark head.

\section{Evaluation of Larvicidal Activity: Toxicity Test}

We used the results of direct fermentation of garlic extraction for larvicide test with a concentration of $100 \%$. Preliminary tests were carried out by making several concentrations of $0.5 \%, 1 \%, 10 \%, 20 \%, 30 \%, 40 \%$ and $50 \%$. We use the preliminary test results as the basis for making concentrations for larvacide testing of fermented garlic extract. Limitation of concentration in testing began with concentrations of $27.5 \%, 25 \%, 22.5 \%, 20 \%$, $17.5 \%, 15 \%, 12.5 \%, 10 \%$ and $7.5 \%$. In the test method, each container filled with $100 \mathrm{ml}$ of extract solution under the treatment concentration and 20 Aedes larvae while in the negative control each replicate filled with distilled water and positive control of abate powder $1 \%$ and larvae were also 10 tails. Tests in both treatment and control were 4 (four) and each replication contained 10 Aedes larvae. During treatment, we fed larvae yeast flour. The larvae are said to die when the larvae stay in the water and cannot rise to the surface again and when touched with a stirring rod, there is no movement response. Concentration treatment is the same for both types of mosquito larvae.

\section{Data Analysis}

LC50 values are obtained using Probit Analysis. Analysis of variance (ANOVA) analyzed mortality observation data. If there is a difference between treatments, then proceed with the Tukey Test at the 5\% test level. If the 
data does not have the same variant, the KruskalWallis test is performed. If the curve obtained is normal, then the Mann-Whitney test is continued.

\section{RESULTS AND DISCUSSION}

\section{Results}

We carried preliminary tests out to determine the concentration range of LC50 as a reference concentration for toxicity testing. Based on Table 4, we can see that the mortality value of Aedes mosquito larvae increases with the increasing concentration of fermented garlic extract. This ensures that the extract is toxic. The extract could cause death by $50 \%$ at a concentration of $20 \%$ and kill $100 \%$ of test animals at a concentration of $30 \%$ with a 24 hour exposure time.

Preliminary test results obtained a concentration value of $20 \%$ which can kill an average of 5 larvae of Aedes mosquitoes (Table $1)$. So that the concentration is the reference in the next stage, namely the toxicity test stage. The concentration chosen to look for LC50 values in the toxicity test stages is $27.5 \%, 25 \%, 22.5 \%$, $20 \%, 17.5 \%, 15 \%, 12.5 \%, 10 \%$ and $7.5 \%$.

\section{Mortality of Aedes aegypti and Aedes albopictus Mosquito Larvae.}

The effect of various concentrations of fermented garlic extract which has been tested in each treatment group. The results of the KruskalWallis test were conducted to determine differences between treatments with an average cumulative number of larval deaths. From the test results obtained $p$-value of $0,000(p<\alpha$; $0,000<0,05)$. That is, there is a difference in the average cumulative number of Ae larval deaths. Aegypt uses fermented garlic extract, abate, and distilled water. To find out which groups have differences, it cannot be known because the data is not normally distributed. But in Table 2 we know that there is a difference between treatments. If we compared the treatment group with the positive control group (abate $1 \%$ ), we know that the results that have differences are $22.5 \%, 20 \%, 17.5 \%, 15 \%, 12.5 \%, 10 \%$, and $7.5 \%$. Treatment at concentrations of $27.5 \%$ and $25 \%$ did not have a significant difference. The difference between negative control (aquadest) and treatment which results in no difference is the concentration of $7.5 \%$ while other concentrations have differences. The results of the statistical analysis with ANOVA showed that the fermented garlic extract solution significantly affected the mortality of Ae mosquito larvae. albopictus. We can see this from the significant value of $p=0,000 ; \alpha=0.05$. The test results were then further tested by the Tukey Test at the 5\% test level to determine the differences between treatments. In the Tukey test, we can see that the difference between treatments was significant between the concentration of fermented garlic and the average mortality of Ae larvae. albopictus, namely at concentrations of $\mathrm{a}, \mathrm{b}, \mathrm{c}, \mathrm{d}$ and $\mathrm{e}$ (Table 3). This means that the five concentrations have different effects on the average mortality of Ae. albopictus mosquito larvae. Based on the results of the Tukey test it was found that concentrations of $0 \%-17.5 \%$ (groups a and b) had no effect on larval mortality, while at concentrations of $20 \%$ $27.5 \%$ (c, d, and e) which showed that concentration it influences larval mortality. Between concentrations of 20 and $22.5 \%$, there was also no significant difference in larval mortality. The most influential concentration on larval mortality is at concentrations of $25 \%$ and $27.5 \%$. Because at this concentration the percentage of larval mortality is highest compared to other concentrations.

As for the probit analysis, we know that LC 50 of garlic fermentation extract in killing $50 \%$ of larvae is $20 \%$ for Ae larvae. aegypti and 21,429\% for Ae larvae. albopictus.

\section{Phytochemical Screening and Content of Fermented Garlic Compounds}

The results of phytochemical screening of fermented garlic extract (Allium sativum L.) can be seen in Table 4 . In Table 4 we know that fermented garlic does not contain or are not identified with alkaloid compounds, flavonoids, saponins, polyphenols, and steroids. However, organophosphorus compounds were identified.

The organosulfur compounds identified in the fermented fraction of ethyl acetate (1: 3) garlic extract using GC-MS are as follows (Table 5) 
Table 1. Larvacide Preliminary Test of Fermented Garlic for 24 Hours on Aedes larvae.

The Concentration of the Number of Dead Larvae Percentage of Larval Mortality Average Percentage

\begin{tabular}{cccccc}
\hline \multirow{2}{*}{ Concentration } & \multicolumn{2}{c}{ The number of dead larvae } & \multicolumn{2}{c}{ Percentage of larval mortality } & Average percentage \\
& I & II & I & II & $0 \%$ \\
$0,5 \%$ & 0 & 0 & $0 \%$ & $0 \%$ & $0 \%$ \\
$1 \%$ & 0 & 0 & $0 \%$ & $0 \%$ & $10 \%$ \\
$10 \%$ & 1 & 1 & $10 \%$ & $10 \%$ & $50 \%$ \\
$20 \%$ & 4 & 6 & $40 \%$ & $60 \%$ & $100 \%$ \\
$30 \%$ & 10 & 10 & $100 \%$ & $100 \%$ & $100 \%$ \\
$40 \%$ & 10 & 10 & $100 \%$ & $100 \%$ & $100 \%$ \\
$50 \%$ & 10 & 10 & $100 \%$ & $100 \%$ & \\
\hline
\end{tabular}

Table 2. Mortality of Mosquito Larvae aegypti which is Exposed to Fermented Garlic Extract for 24 Hours

\begin{tabular}{|c|c|c|c|c|c|c|}
\hline \multirow{2}{*}{ Concentration } & \multicolumn{4}{|c|}{ The number of dead Aedes aegypti larvae } & \multirow{2}{*}{ Average } & \multirow{2}{*}{ Percentage } \\
\hline & I & II & III & IV & & \\
\hline Positive control & 10 & 10 & 10 & 10 & 10 & 100 \\
\hline Negative control & 0 & 0 & 0 & 0 & 0 & 0 \\
\hline 27 & 8 & 9 & 10 & 7 & 9 & 85 \\
\hline & 8 & 6 & 7 & 5 & 7 & 65 \\
\hline 22 & 4 & 6 & 6 & 7 & 6 & 57.5 \\
\hline & 4 & 6 & 5 & 4 & 5 & 47.5 \\
\hline 17 & 3 & 2 & 2 & 3 & 3 & 25 \\
\hline & 1 & 3 & 2 & 1 & 2 & 17.5 \\
\hline 12 & 1 & 2 & 2 & 2 & 2 & 17.5 \\
\hline 1 & 1 & 2 & 1 & 2 & 2 & 15 \\
\hline 7 & 0 & 0 & 0 & 0 & 0 & 0 \\
\hline
\end{tabular}

Table 3. Mortality of Ae Mosquito Larvae Albopictus Which is Exposed to Fermented Garlic Extract for 24 Hours

\begin{tabular}{|c|c|c|c|c|c|c|c|}
\hline \multirow{2}{*}{\multicolumn{2}{|c|}{ Concentration }} & \multicolumn{4}{|c|}{ The number of dead Aedes albopictus larvae } & \multirow{2}{*}{ Average } & \multirow{2}{*}{ Percentage } \\
\hline & & I & II & III & IV & & \\
\hline Positive control & & 10 & 10 & 10 & 10 & $10^{\mathrm{e}}$ & 100 \\
\hline \multirow[t]{10}{*}{ Negative control } & & 0 & 0 & 0 & 0 & $0^{\mathrm{a}}$ & 0 \\
\hline & 27.5 & 7 & 7 & 8 & 7 & $7^{d}$ & 72.5 \\
\hline & 25 & 7 & 6 & 6 & 5 & $6^{\mathrm{d}}$ & 60 \\
\hline & 22.5 & 4 & 7 & 6 & 6 & $6^{\mathrm{c}}$ & 57.5 \\
\hline & 20 & 3 & 4 & 4 & 5 & $4^{c}$ & 40 \\
\hline & 17.5 & 2 & 3 & 2 & 4 & $3^{b c}$ & 27.5 \\
\hline & 15 & 2 & 1 & 2 & 3 & $2^{\mathrm{b}}$ & 20 \\
\hline & 12.5 & 1 & 1 & 2 & 2 & $2^{a b}$ & 15 \\
\hline & 10 & 1 & 0 & 0 & 0 & $0^{\mathrm{a}}$ & 2.5 \\
\hline & 7.5 & 0 & 0 & 0 & 0 & $0^{\mathrm{a}}$ & 0 \\
\hline
\end{tabular}

Note: no effect (a) no effect (b) effect (c) effect (d) effect (bc) no effect (ab) The letters beside the numbers show a significant difference 
Table 4. Phytochemical Test of Fermented Garlic Extract (Allium sativum L.)

\begin{tabular}{|c|c|c|c|}
\hline $\mathrm{NO}$ & Assay & Result & Description \\
\hline 1 & Alkaloid & - & Not formed orange or yellowish deposits \\
\hline 2 & Flavonoid & - & $\begin{array}{l}\text { Color does not form } \\
\text { red, yellow or orange }\end{array}$ \\
\hline 3 & Saponin & - & No foam permanent \pm 15 minutes \\
\hline 4 & Polyphenol & - & $\begin{array}{l}\text { no color is formed } \\
\text { green, blue or purple }\end{array}$ \\
\hline 5 & Steroid & - & $\begin{array}{l}\text { not formed } \\
\text { blue or green, }\end{array}$ \\
\hline 6 & Senyawa organosulfur & + & Sulfur scented \\
\hline
\end{tabular}

Table 5. Organophosphorus Compounds in Fermented Garlic Extract

\begin{tabular}{|c|c|c|}
\hline No & Compounds & $\mathrm{m} / \mathrm{z}$ \\
\hline 1 & 1,2-Propanediol (CAS) Propylene glycol & 45.0 \\
\hline 2 & 2,3-Butanediol (CAS) Butane-2,3-diol & 45.0 \\
\hline 3 & Butanoic acid (CAS) n-Butyric acid & 60.0 \\
\hline 4 & 1,2-Butanediol (CAS) 1,2 Butylene glycol & 59.0 \\
\hline 5 & 2(3H)-Furanone, dihydro-(CAS) Butyrolactone & 42.1 \\
\hline 6 & $\mathrm{Nd}$ & 73.0 \\
\hline 7 & Ethanol,2-butoxy-(CAS) 2-Butoxyethanol & 57.0 \\
\hline 8 & Propane, 1-(1-methylethoxy)-(CAS) Propyl isopropyl ether & 43.0 \\
\hline 9 & Ethanol, 2-(1-methyletoxy)-(CAS) 2-Isopropoxyethanol & 43.1 \\
\hline 10 & Butanoic acid, 3-hydroxy, ethyl ester (CAS) Ethyl 3-hydroxybutyrate & 43.0 \\
\hline 11 & $\mathrm{Nd}$ & 45.0 \\
\hline 12 & 2-pentanone, 4 hydroxy & 43.0 \\
\hline 13 & $\mathrm{Nd}$ & 43.0 \\
\hline 14 & 4-Heptanol, 3-methyl-(CAS) 3-methyl-4heptanol & 55.0 \\
\hline 15 & Phenol & 94.0 \\
\hline 16 & $\mathrm{Nd}$ & 42.0 \\
\hline 17 & $\mathrm{Nd}$ & 60.0 \\
\hline 18 & Iso Valeric acid & 67.1 \\
\hline 19 & Allyl-2,3-epoxypropyl sulfide & 41.1 \\
\hline 20 & 1-(1-Propenylthio) propane & 45.0 \\
\hline 21 & 2,4-Pentanediol (CAS) 2,4 amylene glycol & 45.0 \\
\hline 22 & 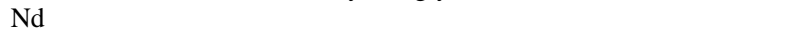 & 63.0 \\
\hline 23 & $\mathrm{Nd}$ & 52.0 \\
\hline 24 & Propanoic acid, 2-methyl-, propyl ester (CAS) propyl isobutyrate & 43.1 \\
\hline 25 & $\mathrm{Nd}$ & 45.0 \\
\hline 26 & $\mathrm{Nd}$ & 44.0 \\
\hline 27 & $\mathrm{Nd}$ & 60.0 \\
\hline 28 & $\mathrm{Nd}$ & 43.0 \\
\hline 29 & 1-Propane, 3 methoxy-2-methyl-(CAS) Methyl 2-methyl allyl ether & 71.0 \\
\hline 30 & $\mathrm{Nd}$ & 109.0 \\
\hline 31 & $\mathrm{Nd}$ & 60.0 \\
\hline 32 & Pentane, 2,2'-oxybis- (CAS) Ether, di-2-pentyl & 71.0 \\
\hline 33 & Benzeneethanol (CAS) phenethyl alcohol & 91.0 \\
\hline 34 & $\mathrm{Nd}$ & 43.0 \\
\hline 35 & $\mathrm{Nd}$ & 65.0 \\
\hline 36 & 1,2-Dithiacyclopentane & 87.0 \\
\hline 37 & $\mathrm{Nd}$ & 41.1 \\
\hline 38 & Decane, 1-chloro-(CAS) 1-Chlorodecane & 91.0 \\
\hline 39 & 3-Pethanol, 2,3,4-trimethyl-(CAS) 2,3,4-Trimethyl-3-pentanol & 43.0 \\
\hline 40 & $\mathrm{Nd}$ & 132.1 \\
\hline 41 & 6,8-Dioxabicyclo (3.2.1) Oktan-2L-OL-2,3-D2 & 88.0 \\
\hline 42 & $\mathrm{Nd}$ & 45.0 \\
\hline 42 & $\mathrm{Nd}$ & 84.0 \\
\hline 43 & Butyl isobutyrate & 71.0 \\
\hline 44 & Ethyl 5,5-diethoxyvalerate & 41.1 \\
\hline 45 & $\mathrm{Nd}$ & 112.0 \\
\hline 46 & 2-Hexanol, 2,4-dimethyl-(CAS) 2,4-Dimethyl-3-hexanol & 43.0 \\
\hline 47 & $\mathrm{Nd}$ & 41.1 \\
\hline 48 & 1,2,4-Trithiolane, 3,5-diethyl-(CAS) 3,5-Diethyl-1,2,4-trithiolne & 41.1 \\
\hline 49 & $\mathrm{Nd}$ & 45.0 \\
\hline 50 & 4-Methoxymethylphenol & 107.0 \\
\hline 51 & 1,2-Ethanediol, 1-phenyl-(CAS) 3,5-Diethyl-1,2,4-trithiolane & 107.0 \\
\hline
\end{tabular}




\begin{tabular}{|c|c|c|}
\hline 52 & $\mathrm{Nd}$ & 43.0 \\
\hline 53 & 2-methyl-oxirane-2-YL)-acetic acid methyl ester & 41.1 \\
\hline 54 & 2-Ethoxyethylallyl ether & 41.1 \\
\hline 55 & $\mathrm{Nd}$ & 111.1 \\
\hline 56 & $\mathrm{Nd}$ & 41.1 \\
\hline 57 & $\mathrm{Nd}$ & 71.0 \\
\hline 58 & 5-Hexenoic acid (CAS) Hex-5-enoic acid & 42.0 \\
\hline 59 & Phenol, 2-methoxy-4-(2-propenyl)-(CAS) Eugenol & 164.0 \\
\hline 60 & Butanoic acid, pentyl ester (CAS) Amyl butyrate & 71.0 \\
\hline 61 & $\mathrm{Nd}$ & 43.0 \\
\hline 62 & 2-Pentene, 2-methoxy-(CAS) & 43.0 \\
\hline 63 & $\mathrm{Nd}$ & 85.0 \\
\hline 64 & 1-Nonanol (CAS) -Nonyl alcohol & 43.0 \\
\hline 65 & $\mathrm{Nd}$ & 43.0 \\
\hline 66 & $\mathrm{Nd}$ & 60.0 \\
\hline 67 & $\mathrm{Nd}$ & 71.0 \\
\hline 68 & 3,3-Dimethoxy-6,6-dimethyl-cyclohexane-1,4-diene & 137.1 \\
\hline 69 & Ethyl 2-ethyl butanoate & 43.0 \\
\hline 70 & $\mathrm{Nd}$ & 41.1 \\
\hline 71 & Pentane,1-(1-ethoxyethoxy)-(CAS) 1-ethoxy-1-pentoxyethane & 73.0 \\
\hline 72 & $\mathrm{Nd}$ & 96.1 \\
\hline 73 & $\mathrm{Nd}$ & 96.0 \\
\hline 74 & 3-Isopropoxy-1,1,1,7,7,7-hexamethyl-3,5,5-tris(trimethylsiloxy)tetrasiloxane & 73.0 \\
\hline 75 & $\mathrm{Nd}$ & 44.0 \\
\hline 76 & $\mathrm{Nd}$ & 88.0 \\
\hline 77 & $\mathrm{Nd}$ & 111.0 \\
\hline 78 & $\mathrm{Nd}$ & 156.1 \\
\hline 79 & $\mathrm{Nd}$ & 137.1 \\
\hline 80 & $\mathrm{Nd}$ & 43.0 \\
\hline 81 & $\mathrm{Nd}$ & 43.0 \\
\hline 82 & 2-Methoxy-4-(methoxymethyl)-phenol & 137.1 \\
\hline 83 & $\mathrm{Nd}$ & 43.0 \\
\hline 84 & $\mathrm{Nd}$ & 71.0 \\
\hline 85 & $\mathrm{Nd}$ & 156.0 \\
\hline 86 & $\mathrm{Nd}$ & 43.0 \\
\hline 87 & Methyl-2(2-hydroxy-3-ethoxy-benzyl) ether & 137.1 \\
\hline 88 & $\mathrm{Nd}$ & 44.0 \\
\hline 89 & $\begin{array}{l}\text { 1-Propanone, 3-(4-hydroxy-4-methyl-1-piperidinyl)-1-phenyl-(CAS) Beta.(4-Methyl } \\
\mathrm{Nd}\end{array}$ & 105. \\
\hline 90 & $\mathrm{Nd}$ & $105 . \mathrm{C}$ \\
\hline 91 & $\mathrm{Nd}$ & 45.0 \\
\hline 92 & $\mathrm{Nd}$ & 137.1 \\
\hline 93 & $\mathrm{Nd}$ & 43.0 \\
\hline 94 & $\mathrm{Nd}$ & 88.0 \\
\hline 95 & $\mathrm{Nd}$ & 73.0 \\
\hline 96 & $\mathrm{Nd}$ & 122.0 \\
\hline 97 & Silicate anion tetramer & 122.1 \\
\hline 98 & Butane, 4-(trimethylsilyl)-1-1((trimethylsilyl) oxy) & 73.0 \\
\hline 99 & $\mathrm{Nd}$ & 73.0 \\
\hline 100 & Bis-(sec-bytoxo)(methyl) oxovanadium & 44.0 \\
\hline 101 & $\mathrm{Nd}$ & 43.0 \\
\hline 102 & Tetraneurin-A-diol & 120.0 \\
\hline 103 & Acetamide, $\mathrm{N}$-(2(4-(acetyloxy)-3-methoxyphenyl) ethyl)-(CAS) 4-acetoxy-N-Acetyl & 97.0 \\
\hline 104 & & 150.1 \\
\hline
\end{tabular}

\section{Mortality}

Based on the results, we can see that the concentration of fermented garlic extract which caused the death of test larvae was a concentration of 10 to $27.5 \%$ with a percentage ranging from 15 to $85 \%$ in testing with $\mathrm{Ae}$ larvae. aegypti and $2.5-72.5 \%$ in testing with Ae larvae. albopictus (Table 2 and Table 3). the negative control group (aquades) did not have test larvae that died. In the positive control, there were $100 \%$ test larvae mortality. This proves that there is an effect of fermented garlic extract on the death of Aedes larvae. Chemical compounds can cause the high mortality rate of test larvae in fermented garlic which play a role in biological activity in the growth and development of larvae. We widely known organophosphate compounds as insecticides. The compounds that are mostly contained in garlic include organophosphorus groups. The organophosphorus group works on the nervous system, which inhibits the action of the enzyme acetylcholine esterase. The 
organophosphorus group is a fat-soluble compound, easily absorbed by the skin, oral mucous membranes, respiratory and digestive tract surface membranes. Thus the organoposfor compounds of the level of safety and toxicity are very much determined by the length of exposure, the dose, the route and the average metabolism (Karalliedde et al., 2003). This causes the larvae to be disturbed by their metabolism, causing the death of larvae before developing into pupae. Larvicidal mechanism of action in killing larvae that is larvacide enters through contact with the skin. Then it is applied directly through the insect integument (cuticle), trachea or sensory glands and other organs associated with the cuticle.

Chemicals in insecticides dissolve fat or wax coating on the cuticle, causing the active ingredients in the insecticide to penetrate the insect's body (Pradani et al., 2011). This larvicide can also enter the body of the larvae through the mouth of the larva (through food eaten). The larvae die because of the toxins that enter through the food then in the cells of the body the mosquitoes will inhibit cell metabolism which is inhibiting electron transport in the mitochondria so that the formation of energy from food as an energy source in the cell does not occur and the cell cannot move, this causes the larvae to die.

Organophosphorus compounds found in garlic, which are known as insecticides, are diallyl disulfide and diallyl trisulfide (Amonkar \& Banerji, 1971)(Moon, 2011), which are derivatives of allicin. We do not find this compound in fermented garlic extract. However, the compound found in fermented garlic belonging to allicin derivatives is allyl-2,3epoxypropyl sulfide. This compound is responsible as an antifeedant, repellent and toxic in some pests (Vijayalakshmi et al., 1996). This compound is one of which is thought to be an insecticide in fermented garlic. This is the first information to report that fermented garlic extract is larvicidal.

Probit analysis is known that the average LC50 value of fermented garlic extract concentration is $20 \%$ for Ae larvae. aegypti and $21,429 \%$ for Ae larvae. albopictus. This means that the concentration of fermented garlic extract can kill $50 \%$ of the total Ae larvae. aegypti test at a concentration of $20 \%$ and at intervals of 20 and $22.5 \%$ in Ae larvae. albopictus.

In Tables 2 and 3, the mortality between Aedes aegypti and Aedes albopictus larvae with fermented garlic extract is different. This is seen from the range of percentage of mortality where, the percentage of mortality in Ae. aegypti 15$85 \%$ and on Ae. albopictus ranges from 2.5 to $72.5 \%$. The concentration of garlic extract which causes dead larvae is the same, namely the concentration of $10-27.5 \%$, but is different in terms of the number of larvae that die at each concentration. The number of larvae that die at this concentration is higher in Ae larvae. aegypti compared to Ae larvae. albopictus.

The average number of larvae that die is lowest in Ae. aegypti is 2 tails at a concentration of $10 \%$ and the highest is 9 tails at a concentration of $27.5 \%$. Whereas the average number of larvae that died in Ae. The lowest albopictus was 1 at $10 \%$ concentration and the highest was 7 at a concentration of $27.5 \%$. LC 50 for Ae larvae. aegypti is also different where for Ae larvae. aegypti is $20 \%$ and Ae. albopictus $21,429 \%$. Many factors cause this difference, one of which is the type of mosquito species itself. This means that each different species will have a difference in responding to its environment, including in response to insecticides. The results are like those of (Zhu et al., 2006), where larvae of Ae. aegypti is more susceptible to insecticide exposure compared to Ae larvae. albopictus. (Cheng et al., 2009) reported LC 50 of Clausena exavata essential oil was lower than LC 50 (85 mgmL-1; 24 hours) for Ae larvae. albopictus (78 mgmL-1; 24 hours). Ae larvae. aegypti is more sensitive to Clausena exavata essential oil compared to Ae larvae. albopictus.

In Table 2 we know that there is a difference in mortality of Ae larvae. aegypti at every concentration. The higher the concentration of fermented garlic extract, the higher the larval mortality. This is because the concentration / dose of the extract will determine the number of active compounds they contain. The higher the concentration, the higher the content of the active compound, resulting in higher larval mortality. Here, at high concentrations the content of organophosphorus active compounds is high in fermented garlic 
extract. The insecticide rose determines the level of toxicity (Karalliedde et al., 2003).

In Table 3 we know that there is a difference in mortality of Ae larvae. albopictus at different concentrations. Concentration of fermented garlic extract has a different effect on the average mortality of larvae. Based on the results of the Tukey test, it was seen that concentrations of $0-17.5 \%$ (groups a and b) did not affect larval mortality, while at concentrations of $20-27.5 \%$ (c, d) showed that these concentrations had a significant effect on mortality. Larvae. Between concentrations of 20 and $22.5 \%$ there was also no significant difference in effect on larval mortality. The most influential concentration on larval mortality is at concentrations of 25 and $27.5 \%$. The concentration of $12.5-17.5 \%$ is the larvicidal concentration, which can still be tolerated by larvae. At this concentration the larvae do not experience a metabolic disturbance so the concentration of the larvicidal active compound is small. Whereas the larvicidal concentration of $25-27.5 \%$ is the concentration in which larvae cannot tolerate it, which is characterized by high larval death because of disturbed metabolism. The insecticide dose, route and average larval metabolism determine the level of toxicity (Karalliedde et al., 2003). High larvicidal concentrations are increasingly toxic to larvae.

\section{Phytochemical Screening and Content of Fermented Garlic Compounds}

The results of phytochemical screening of fermented garlic extract (alkaloids, flavonoids, saponins, polyphenols and steroids) were not conceived/ not identified. However, organophosphorus compounds were identified. This is because in addition to the amount/ concentration of these compounds which are very low in garlic, it is also possible because of the breakdown of these compounds due to the fermentation process by Tempe mushrooms. While many organophosphoruses in garlic remains widely identified, although different from organophosphorus compounds in garlic extract. 104 organophosphorus compounds were found, we identified of which 49 and 55 unknown compounds (Nd) (Table 4.5). One of the allicin organophosphorus derivatives, allyl2,3-epoxypropyl sulfide, was found in fermented garlic extract. In fresh garlic extract methyl-2- propenyl was found, 1,3 dithiin, diallyl disulfide, allylpropenyl disulfide, 3-vinyl-1,2dithiocyclohexana, 3-vinyl-1,2-dithiocyclohex5-en, allicin, $\gamma$ - glutamyl-S-allycystein (Roy et al., 2006). The compounds in this garlic extract were no longer identified with fermented garlic extract. The results are also different from the results of the research by (Yusuf \& Bewaji, 2011), where garlic ethanol extract contains 2,3pentanedion, 1-octane, 1-hexadecane, Nonadecane, hexadecanoic acid, octadecanoic acid, octacosane, hexacosane, tetracosane-1 -ol, octadecene-18-olide and 5-octadecene.

\section{CONCLUSION}

Based on the research that has been done, the following conclusions are there are differences in mortality of Aedes aegypti and Aedes albopictus larvae with fermented garlic extract. Mortality of Ae larvae. aegypty is higher than Ae's mortality. albopictus. Value of LC 50 for Ae larvae. aegypty is lower (20\%) than the LC 50 value for Ae larvae. albopictus $(21,429 \%)$. There is a difference in mortality of Ae larvae. albopictus at different concentrations of fermented garlic extract. We found significant differences at concentrations of 20-27.5\%. No alkaloid compounds, flavonoids, saponins, polyphenols and steroids in fermented garlic extract were found. We identified 49 organophosphorus compounds on fermented garlic extract. We found only one allicin derivative, namely allyl-2,3-epoxypropyl sulfide.

\section{REFERENCES}

Amonkar, S., \& Banerji, A. (1971). Isolation and Characterization of Larvicidal Principle of Garlic. Science, 174(4016), 1343-1344. https://science.sciencemag.org/content/17 4/4016/1343.abstract

Amonkar, S., \& Reeves, E. (1970). Mosquito Control with Active Principle of Garlic, Allium sativum. Journal of Economic Entomology, 63(4), 1172-1175.

Budiyanto, A., Santoso, S., Purnama, D., \& Pahlepi, R. I. (2007). Studi Indeks Larva Nyamuk Aedes Aegypti dan Hubungannya dengan Psp Masyarakat tentang Penyakit 
DBD di Kota Palembang Sumatera Selatan Tahun 2005. Buletin Loka Litbang P2B2 Baturaja, 1(1).

Cheng, S. S., Chang, H. T., Lin, C. Y., Chen, P. S., Huang, C. G., Chen, W. J., \& Chang, S. T. (2009). Insecticidal activities of leaf and twig essential oils from Clausena excavata against Aedes aegypti and Aedes albopictus larvae. Pest Management Science, 65(3), 339-343. https://doi.org/10.1002/ps.1693

Chin, J. (2006). Manual Pemberantasan Penyakit Menular (I Nyoman K, pp. 166170). Infomediaka.

Coppi, A., Cabinian, M., Mirelman, D., \& Sinnis, P. (2006). Antimalarial activity of allicin, a biologically active compound from garlic cloves. Antimicrobial Agents and Chemotherapy, 50(5), 1731-1737. https://doi.org/10.1128/AAC.50.5.17311737.2006

Delfita, R., \& Putra, A. I. (2015). Pembuatan bawang putih tanpa aroma (Allium sativum L.) menggunakan fermentasi dengan jamur tempe dan uji aktivitas antioksidannya. Prosiding Seminar Nasional Biologi Dan Pendidikan Biologi STKIP PGRI Padang.

Focks, D. A. (2003). A Review Of Entomological Sampling Methods And Indicators For Dengue Vectors. World Health Organization.

Foster, W. A., \& Walker, E. D. (2002). Medical and veterinary entomology $(\mathrm{G}$. Mullen \& L. Durden (eds.)). Academic Press.

González-Coloma, A., Reina, M., Díaz, C. E., Fraga, B., \& Santana-Méridas, O. (2010). Natural Product-Based Biopesticides for Insect Control.

Gubler, D. J. (1998). Dengue and dengue hemorrhagic fever. Clinical Microbiology, 11(3), 480-496. https://doi.org/10.1128/cmr.11.3.480

Harborne, J. (1973). Phytochemical methods. Chapman and Hall Ltd.

Hasyimi, H., \& Soekirno, M. (2004). Pengamatan Tempat Perindukan Aedes aegypti pada Tempat Penampungan Air Rumah Tanggga pada Masyarakat Pengguna Air Olahan. Jurnal Ekologi Kesehatan, 3(1), 37-42.

HorasNews. (2016). Belasan Warga Terkapar Karena DBD. http://horasnews.com/belasan-wargaterkapar-karena-dbd/. Dikases 29 Maret 2016.

Huzaifa, U., Labaran, I., Bello, A. B., \& Olatunde, A. (2014). Phytochemical screening of aqueous extract of garlic (Allium sativum) bulbs. Rep Opinion, 6(8), $1-4$.

Karalliedde, L. D., Edwards, E., \& Marrs, T. C. (2003). Variables influencing the toxic response to organophosphates in humans. Food and Chemical Toxicology, 41, 1-13.

Kemenkes RI. (2010). Demam Berdarah Dengue di Indonesia Buletin Jendela Epidemiologi. Vol 2.

Media Info Kota. (2012). Fogging Bukan Solusi Terbaik, Lakukan $3 \mathrm{~m}$ Plus. http://mediainfokota.jogjakota.go.id/detail .php?berita_id=126. Dikases 29 Maret 2016.

Moon, H. I. (2011). Larvicidal activity of major essential oils from stems of Allium monanthum Maxim. against Aedes aegypti L. Journal of Enzyme Inhibition and Medicinal Chemistry, 26(6), 827-830. https://doi.org/10.3109/14756366.2011.55 8842

Pradani, F. Y., Ipa, M., Marina, R., \& Yuliasih, Y. (2011). Penentuan Status Resistensi Aedes aegypti dengan Metode Susceptibility di Kota Cimahi terhadap Cypermethrin. Jurnal Vektora, 3(1), 3543.

Regnault-Roger, C., Hamraoui, A., Holeman, M., Theron, E., \& Pinel, R. (1993). Insecticidal effect of essential oils from mediterranean plants upon Acanthoscelides Obtectus Say (Coleoptera, Bruchidae), a pest of kidney bean (Phaseolus vulgaris L.). Journal of Chemical Ecology, 19(6), 1233-1244. https://doi.org/10.1007/BF00987383

Roy, J., Shakleya, D. M., Callery, P. S., \& Thomas, J. G. (2006). Chemical constituents and antimicrobial activity of a traditional herbal medicine containing garlic and black cumin. Afr. J. Trad. CAM, $3(2), 1-7$.

Rozendaal, J. (1997). Vector control: methods for use by individuals and communities. World Health Organization. https://books.google.com/books?hl=id\&lr 
$=\& \mathrm{id}=\mathrm{z} 6 \mathrm{H} 5 \mathrm{gwdddREC} \& \mathrm{oi}=\mathrm{fnd} \& \mathrm{pg}=\mathrm{PR} 9$ $\& d q=$ Rozendaal+JA.+Vector+Control.+(1 997).+Methods+for+Use+by+Individual+ and+Communities.+Geneva:+World+Heal th+Organization. $+7+-177$.\&ots $=-$ z6FDjgjTx\&sig=K2a3z1QPxPMZuMWs4 wPAx9kH1E0

Sanchez, L., Vanlerberhe, V., Alfonso, L., Marqetti, M. C., Guzman, M. G., \& Bisset, J. (2006). Aedes aegypti larval indices and risk for dengue epidemics. Emerging Infectious Diseases, 12(5), 800-806.

Taboada, O. (1967). Medical Entomology. National Naval Medical Center.

Vijayalakshmi, K., Subhashini, B., \& Shivani, V. K. (1996). Plant in pest control: garlic and onion. Centre for Indian Knowledge System.

Widiarti, Heriyanto, B., Boewono, D. T., Widyastuti, U., Mujiono, Lasmiati, \& Yuliadi. (2011). Peta Resistensi Vektor Demam Berdarah Dengue Aedes aegypti terhadap Insektisida kelompok Organofosfat, Karbamat dan Pyrethroid Di Provinsi Jawa Tengah Dan Daerah. Buletin Penelitian Kesehatan, 39(4), 176-189.

World Health Organization. (2005). Panduan
Lengkap. Pencegahan dan Pengendalian Dengue dan Demam Berdarah Dengue. . Kedokteran EGC.

Yang, F. L., Zhu, F., \& Lei, C. L. (2012). Insecticidal activities of garlic substances against adults of grain moth, Sitotroga cerealella (Lepidoptera: Gelechiidae). Insect Science, 19(2), 205-212. https://doi.org/10.1111/j.17447917.2011.01446.x

Yusuf, O. K., \& Bewaji, C. O. (2011). Evaluation of essential oils composition of methanolic Allium sativum extract on Trypanosoma brucei infected rats. Research In Pharmaceutical Biotechnology, 3(2), 17-21.

Zhu, J., Zeng, X., Ma, Y., Liu, T., \& Han, Y. (2006). Adult Repellency and Larvicidal Activity of Five Plant Essential Oils Against Mosquitoes. Journal of the American Mosquito Control Association, 22(3), 515-522. https://doi.org/10.2987/8756971X(2006)22[515:ARALAO]2.0.CO;2 